\title{
The Influence of Islamic Tourism on Word of Mouth about Tourism in West Sumatra
}

\author{
Yollanda Yollanda ${ }^{1}$ Yunia Wardi² Abror Abror ${ }^{3}$ \\ ${ }^{1}$ Universitas Negeri Padang, PadangandIndonesia, $\square$ (e-mail) yollanda.mirza@yahoo.com \\ ${ }^{2}$ Universitas Negeri Padang, Padang and Indonesia, $\square$ (e-mail) yuniawardi@yahoo.co.id \\ ${ }^{3}$ Universitas Negeri Padang, Padang and Indonesia, $\square$ (e-mail) abror094@gmail.com
}

\begin{abstract}
This study aims to analyze the influence of Islamic tourism on the word of mouth about tourism in West Sumatra. Respondents in this study are tourists who visit West Sumatra. This study used 345 respondents as the sample. The data analysis technique of this study is multiple linear regression analysis. The results showed that Islamic facilities, halalness, alcoholic drinks and gambling free have positive and significant effect on word of mouth. Meanwhile, Islamic culture has insignificant effect on word of mouth about tourism in West Sumatra. Furthermore, some limitations and future study are discussed
\end{abstract}

Keywords: islamic facilities, halalness, islamic culture, free from gambling and alcoholic beverages, word of Mouth

\section{Introduction}

Tourism is a complex, multidisciplinary and multidimensional activity, involving various sectors including the government and its stakeholders; business, society, and tourists. Tourism is one of the fastest growing industrial sectors and a global economic support sector. By 2015 the number of international tourist arrivals to various tourist destinations worldwide has increased $4.4 \%$ since 2010, reaching a total of 1,184 million tourists (UNWTO, 2015). According to Kemenpar (2016) Halal tourism (Islamic tourism) has the potential that needs to be maximized by the actors of tourism industry and government. Globally, the growth of halal tourism averages $6 \%$ faster than other tourism subsectors. Ministry of Tourism and Creative Economy has launched several provinces that will be developed into halal tourism in Indonesia. One of the areas that will be developed into halal tourism is the province of West Sumatra. In addition, in 2016, West Sumatra was also named the Best Halal Tourism and Best Halal Culinary by World Halal Tourism Awards (WHTA) held in Abu Dhabi, Uni Emirat Arab.

As written by Zamani-Faharani and Henderson (2010) stating that Islamic tourism and Halal tourism is the same concept. They define Islamic tourism as a tourism that aims to serve Muslims, thus ensuring the kosherness of various aspects of his tour. But according to Battour (2017) and Wardi, Abror\&Trinanda (2018) research on Islamic tourism and halal tourism is still limited.

According to Kemenpar (2016) halal tourism has the potential to be maximized by the actors of the tourism industry and the government. Globally, the growth of halal tourism is on average $6 \%$ faster than other tourism subsectors. Muslim tourists in the world reached USD145 billion from about 108 million people.Until 2020, the number of Muslim tourists is estimated to reach 150 million people. Thus, halal tourism is considered to have a pretty good prospect in the development of tourism in Indonesia.

Halal tourism is wider than religious tourism, which is based on Islamic values. According to Akyol (2014), tourism has various social and cultural impacts. Halal tourism is a new product of both 
Muslim and non-Muslim markets. According to Zulkifli in Akyol \& Kilinç (2014), halal markets are classified into 3 (three) categories: food, lifestyle (cosmetics, textiles, etc.), and services (package tours, finance, transportation). According to Pavlove in Razzaq, Hall \&Prayag, Halal or Islamic Tourism is defined as tourism and hospitality that is created by consumers and producers according to Islamic teachings. Many countries in the Islamic world are taking advantage of the rising demand for Muslim-friendly tourist services (Razzaq, Hall, \&Prayag, 2015). While according to SaptaNirwandar (2015) in (Achyar, 2015) Halal tourism is extended services. Halal tours can go hand in hand with others

Battour et al (2017) identify Islamic attributes that can attract Muslim tourists as Islamic facilities such as mosques and prayer rooms, halal food, Islamic entertainment, Islamic dress, Islamic moral in general, and Islamic vocation in worship. Based on the attributes that Battour refer, researchers examined 4 attributes or variables in Islamic tourism that are Islamic facility, halalness, Islamic culture, and alcoholic drinks and gambling free. In fact, in the atmosphere of Islamic tourism in West Sumatra has not been so promote for tourists, because the atmosphere of tourism facilities has not been managed properly by the community and government. This can be seen by the existing Islamic tourism facilities. The contribution of the tourism sector in the West Sumatra economy is currently at 38.21 percent. The high or low contribution of the tourism sector in the formation of the value of West Sumatra GDP is certainly determined by the expenditure of foreign tourists who visited the destination region of West Sumatra, including investment in tourism services business such as the provision of hotel services and services provision of food and beverages in restaurants and homes eating with the typical treats of Minangkabau cuisine.

According to Sernovitz (2009), word of mouth is a conversation that naturally occurs between people. Word of mouth is the original consumer talk. According to Ivanovic and Collin (2004), "word of mouth communication is an informal channel of communication like friends and neighbours, colleagues and family members." According to Sernovitz (2009), "word of mouth is so effective because the origin of trust is coming from people did not benefit from their recommendation.

Word of mouth not only forms compliments, recommendation and information but also negative comment. In this era of digitalisation, people easily find to communicate, searching information and do business online. Information disseminated through social media such as facebook, twitter, instagram, and other social media, is a form of negative word of mouth that easily spread through the mediation of the internet. With the ease of dissemination of information (word of mouth), the community and the government that manages West Sumatra tourism should strive to maintain the satisfaction of the tourists, especially through Islamic tourism which becomes the power of West Sumatra tourism. Word of mouth is a compliment, customer recommendations and comments around their experience of services and products that really affect the customer's decision or their buying behaviour. Word of mouth can form the trust of customers.

The quality of Islamic Tourism services in this case Islamic facilities, halal, Islamic culture and alcohol drinks and gambling free is a very important element for Muslim tourists to feel at home to visit tourist destinations in an area Based on tests conducted by some previous researchers, researchers suspect that the factors of service quality in Islamic Tourism have a positive and significant effect on Word of Mouth. Based on this background, the researchers are interested in conducting research with the title: The Influence of Islamic Tourism Against Word of Mouth About Tourism in West Sumatra.

\section{Methods}

This research is a causative research that determines the influence of Islamic Tourism on Word of Mouth. Population in this study was Muslim tourists who made tourist visits in West Sumatra. Data collected by using questionnaires by giving or distributing questionnaires to respondents. This 
research used survey technique with 345 respondents. The method of analysis used in this study is multiple linear regression analysis that analyzes the effect of independent variables on the dependent variable. Before the main analysis, we have conducted some preliminary analysis, such as normality, homogeneity of variance, muticollinearity and outlier test (Abror, \& Akamavi, 2015; Patrisia, \& Dastgir, 2017)

\section{Results and Discussion}

Data analysis model used is multiple regression analysis, that is know how far influence of independent variable to another set of variable which is dependent variable. The following is the result of the first substructure of analysis in this study:

Table 1. Results of Calculation of Second Sub-Structure

\begin{tabular}{lcccc}
\hline \multicolumn{1}{c}{ Variable } & Coefficient & t-value & Sig. & Result \\
\hline Islamic Facility $(X 1)$ & 0,238 & 2.943 & 0,003 & Significant \\
\hline Halal $(X 2)$ & 0,182 & 3,009 & 0,003 & Significant \\
\hline Islamic Culture $(X 3)$ & $-0,058$ & $-0,811$ & 0,418 & Not Significant \\
\hline $\begin{array}{l}\text { Alcoholic Drinks and Gambling } \\
\text { Free }(X 4)\end{array}$ & 0,415 & 7,307 & 0,000 & Significant \\
\hline R Square = 0,361 & & & & \\
\hline$\quad$ Source: Primary Data Processed (2018) & & & &
\end{tabular}

Source: Primary Data Processed (2018)

From the above results, the coefficient of each independent variable along with $t$ test results as follows:

a. The coefficient of Islamic Facilities to Word of Mouth is 0.238 and t-value is 2,943 on sig. 0,003 which is smaller than alpha 0,05.This result shows there is effect of Islamic Facilities to Word of Mouth

b. The coefficient of Halal to Word of Mouth is 0.182 and t-value of 3.00 on the sig. 0,003 which is smaller than alpha 0,05. This result shows there is effect of Halal to Word of Mouth

c. The coefficient of Islamic Culture to Word of Mouth is -0.058 and t-value is -0.811 on sig. 0.418 greater than alpha 0.05 . This result shows there is no effect of Islamic Culture to Word of Mouth

d. The coefficient of free from gambling and alcoholic beverages to Word of Mouth is 0.415 and tvalue of 7.307 on the sig. 0.000 which is smaller than alpha 0.05 . This result shows there is effect of alcoholic drinks and gambling free toWord of Mouth.

From the above calculation, it shows that the coefficient is not significant, that is the coefficient of Islamic Culture on Word of Mouth. Because there is no significant coefficient, it needs to be fixed by using Trimming Model. The following is the result of the substructure after Trimming:

Table 2. Results of Re-Testing of Second Sub-Structure

\begin{tabular}{lcccc}
\hline \multicolumn{1}{c}{ Variable } & Coefficient & t-value & Sig. & Result \\
\hline Islamic Facility $(X 1)$ & 0,241 & 2.977 & 0,003 & Significant \\
\hline Halal $(X 2)$ & 0,180 & 2,980 & 0,003 & Significant \\
\hline $\begin{array}{l}\text { Alcoholic Drinks and Gambling Free } \\
(X 4)\end{array}$ & 0,417 & 7,341 & 0,000 & Significant \\
\hline
\end{tabular}

R Square $=0,359$

Source: Primary Data Processed (2018) 
The calculations show that there is an influence of Islamic Facilities on Word of Mouth, the influence of Halal on Word of Mouth, the influence of free from gambling and alcoholic beverage against Word of Mouth. Based on the above calculation, it can be shown the analysis diagram as follows:

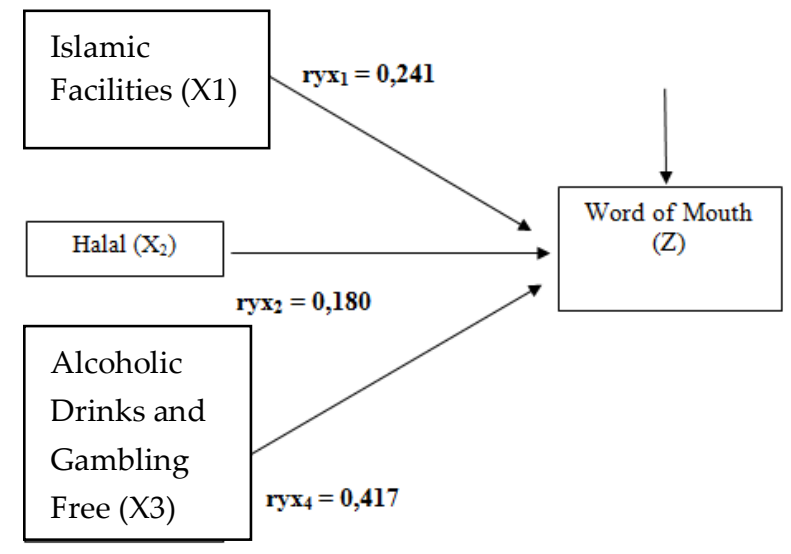

Figure 1. Model

\section{Hypothesis testing}

\section{Hypothesis 1}

From result of analysis test show value of coefficient for Islamic facility (X1) to word of mouth (Y) is 0,241 with sig value. $0.003<0.05$ then $\mathrm{H} 0$ is rejected and Ha is accepted. Means there is significant influence between Islamic facilities (X1) to word of mouth (Y) in West Sumatra.

\section{Hypothesis 2}

From result of analysis test show coefficient value for variable of halal (X2) to word of mouth $(\mathrm{Y})$ is 0,180 with sig value. $0.003<0.05$ then $\mathrm{HO}$ is rejected and Ha accepted. Means there is significant influence between halal (X2) to word of mouth (Y) in West Sumatra.

\section{Hypothesis 3}

From result of analysis test show coefficient value of Islamic cultural variable (X3) to word of mouth (Y) (Pyx3) equal to $-0,058$ with sig. 0.811>0.05 then $\mathrm{H} 0$ is accepted and Ha is rejected. Means there is no significant influence between Islamic Culture (X3) to word of mouth (Y) in West Sumatra.

\section{Hypothesis 4}

From result of analysis test show coefficient value of alcohol drinks and gambling free (X4) to word of mouth (Y) (Pyx4) equal to 0,417 with sig value. $0.000<0.05$ then $\mathrm{H} 0$ is rejected and Ha accepted. Means there is a significant influence between Alcoholic drinks and gambling free (X4) to word of mouth $(\mathrm{Y})$.

\section{Discussion}

The Influence of Islamic Facilities on Word of Mouth of Tourism in West Sumatra

Based on the analysis, it shows that Islamic facilities have a positive and significant effect on word of mouth in West Sumatra. The good and prepared Islamic facilities will increase the word of mouth of tourists in West Sumatra. Variable Islamic facilities have a significant effect on word of mouth, meaning that the findings show that Islamic facilities provide meaning or contribution to the word of mouth. The results of this study are in line with the results of research Batour (2017) which shows there are four attributes in Islamic Tourism which is Islamic facilities, halalness, Islamic culture, and 
alcoholic drinks and gambling free. In addition the result of this study show an outcome similar to Sernovitz (2009) that found word of mouth is so effective because the origin of trust is coming from people who did not benefit from their recommendation. If the availability of Islamic facilities is well managed by the government then it can affect the word of mouth tourists.

The Influence of Halalness on Word of Mouth of Tourism in West Sumatra

Based on the analysis above, it shows that Halalness has positive and significant influence on the word of mouth of tourists in West Sumatra. The better the halalness it will increase the word of mouth tourists in West Sumatra. Variables Halalness significant effect on the word of mouth tourists, meaning that the findings show that halalness provides meaning or contribution to the word of mouth tourists. The results of this study in line with the results of research Battour (2017) which shows the attributes in Islamic Tourism is an Islamic facility, halalness, Islamic culture, and alcoholic drinks and gambling free. If the halalness of the visited tourist spot is high then it can affect the word of mouth of tourists.

The Influence of Islamic Culture on Word of Mouth of Tourism in West Sumatra

Based on the analysis above it shows that Islamic culture has no significant effect that influences the word of mouth of tourism in West Sumatra. That is, the level of word of mouth is not influenced by Islamic cultural variables. This proves that if hotel / inn and restaurant employees use Islamic dress, many people use Islamic dress (example of hijab) in public places, the Government prohibits the practice of prostitution, the Government prohibits sexual activity in public areas (eg kissing etc.), and The government prohibits adult scenes on TV are not the factors that can be the cause ofcompliment, customer recommendations and comments around their experience of services

Islamic culture has no positive and significant effect on word of mouth. The results of Batour's research (2017) which shows there are four attributes in Islamic Tourism from the journal The Role of Destination Attributes in Islamic Tourism by Battour et al (2017) are Islamic facilities, halal, Islamic culture, and free from gambling and alcoholic beverages. Islamic culture has no influence or contribution to the word of mouth of tourists.

The Influence of Alcoholic Drinks and Gambling Free on Word of Mouth of Tourism in West Sumatra

The result shows that the free from gambling and alcoholic drinks have a positive and significant impact on Word of Mouth in West Sumatra. The Better Free of gambling practices and alcoholic beverages will increase Word of Mouth that is praise and recommendation travelers in West Sumatra. The independent variable of alcoholic drinks and gambling free have a significant effect on the Word of Mouth travelers, meaning that the findings show that Free from gambling and alcoholic beverages give meaning or contribution to Word of Mouth tourists.

The results of this study are in line with the results of Battour et. al., (2017) that shows that there are four attributes in Islamic Tourism, namely Islamic facilities, halalness, Islamic culture, and free from gambling and alcoholic beverages. By there is no alcohol and practice of gambling in West Sumatra, tourist or travelers will feeling safe because most of criminal cases has been done due to alcohol and gambling practices.

\section{Conclusions}

Based on the results of data analysis and discussion, it can be taken as follows: (1) Islamic Facilities (X1) have a positive and significant effect on word of mouth about Tourism in West Sumatra(Y); (2) 
Halal (X2) have a positive and significant effect on word of mouth about Tourism in West Sumatra(Y); (3) Islamic Culture (X3) has insignificant effect that influence word of mouth about Tourism in West Sumatra(Y); (4) Alcohol drinks and gambling free (X4) have a positive and significant influence on Word of Mouth on Tourism in West Sumatra.

Based on the findings of research and conclusions obtained in this study, the suggestions that authors can give to improve the word of mouth about tourism in West Sumatra are as follows: (1) Prohibits the practice of gambling and alcoholic beverages by way of the Government prohibits the distribution of alcoholic drinks and gambling in public areas (2) Increase halal food has been available at tourist sites, malls, hotels, etc. Hotels / inns and restaurants provide halal kitchens, tourist sites provide a special place for women (such as beaches, SPA places etc), and hotels / inns protect TV channels from pornography; (3) Increasing Islamic facilities means that Mosque and facilities of worship of tourist sites should be available in sufficient quantities. Adzan can be heard easily when the time of prayer entered. Hotel has provided prayer mats and provide Qur'an in every room. Clean water and squat closets should be available at mall and hotels / lodgings restroom.

\section{References}

Abror, \& Akamavi, R. K. (2015). Psychological safety and organisational performance in Indonesian companies: Preliminary findings Applied Psychology (pp. 8-38): World Scientific.

Achyar, Mahfud. (2015). Indonesia sebagai tujuan halal tourism, (Online), (https://achyar89.wordpress.com, accessed on 10 Oktober 2017)

Battour, Mohamed \&Moh.Nazari Ismail. (2014). The role of destination attributes in islamic tourism, (Online), (http://www.shs-conferences.org, accessed on 2 Oktober 2017)

Battour, Mohamed \&Moh.Nazari Ismail. (2015). Halal tourism: concepts, practices, challenges and future. Tourism Management Perspective Journal Vol:6, No:11

Battour, Mohamed \&Moh.Nazari Ismail. (2017). Islamic Tourism: an empirical examination of travel motivation and satisfaction in Malaysia, (Online), (http://www.tandfonline.com, accessed on 2 Oktober 2017)

Bowden, J.L.H. (2009). "The process of customer engagement: A conceptual framework". Journal of Marketing Theory and Practice 17 (1), 63-74

Brodie, K .(2011). Teaching mathematical reasoning in secondary schools. New York: Springer.

Collin, P.H danIvanovic A. (2004). Dictionary of Marketing. Third.Edition. Bloomsbury Publishing Plc. United States Of America.

Kilinç, Akyol. (2014). "Internet and Halal Tourism Marketing".International Periodical for The Languages, Literature and History of Turkish or Turkic Vol 9, halaman 171-186

Kemenpar.(2016). Kemen parekraf Promosikan Indonesia Sebagai Destinasi Pariwisata Syariah Dunia.(Online), (http://www.kemenpar.go.id, diakses 2 Oktober 2017)

Mowen, John. Michael Minor. (2002). PerilakuKonsumen. Jakarta. Erlangga.

Patrisia, D., \& Dastgir, S. (2017). Diversification and corporate social performance in manufacturing companies. Eurasian Business Review, 7(1), 121-139. doi: 10.1007/s40821-016-0052-6

Razzaq, Sherin., Hall, C. Michael., \&Prayag, Girish. (2015). The capacity of new zealand to accommodate the halal tourism market - or not.(Online), https://canterburynz.academia.edu:https://www.academia.edu/12107406-/The_capacity_of_New_Zealand_to_accommodate_the_halal_tourism_market_or_not

Sernovitz.(2009). Word of Mouth Marketing: How Smart Companies Get. People Talking (Revised Edition). New York : Kaplan Publishing

Wardi, Y., Abror, A., \&Trinanda, O. (2018). Halal tourism: antecedent of tourist's satisfaction and word of mouth (WOM). Asia Pacific Journal of Tourism Research, 23(5), 463-472. doi: 10.1080/10941665.2018.1466816 
Zamani-Farahani, Hamira \& Joan C. Henderson.(2010). Islamic tourism and managing tourism development in islamic societies: the cases of Iran and Saudi Arabia. International Journal of Tourism Research (12) 79-89 